\title{
Entrepreneurial social identities and nascent entrepreneur- ial behaviour: Mediating role of entrepreneurial self-efficacy
}

\author{
Majid Murad, Sheikh Farhan Ashraf, Nausheen Syed, \\ Muhammad Munir, Rehan Sohail Butt
}

\begin{abstract}
A B S T R A C T
Objective: The objective of this article is to investigate the influence of entrepreneurial social identities (Darwinian, missionary, and communitarian) on nascent entrepreneurial behaviour with the mediating effect of entrepreneurial self-efficacy.

Research Design \& Methods: The study is based on a research sample of 455 students from public sector universities of Punjab, Pakistan. The survey questionnaire was developed along with PLS-SEM partial least squares structural equation modelling technique to examine the research model and hypotheses.

Findings: The findings indicate that (Darwinian, missionary, and communitarian) social identities are positively and significantly related to nascent entrepreneurial behaviour. The results also show that entrepreneurial self-efficacy is a key mediator that affects the relationship between social identities and nascent entrepreneurial behaviour.

Implications \& Recommendations: The findings have important practical and academic implications for both universities and policymakers to foster student's entrepreneurial social identities and develop an entrepreneurial nascent behaviour to become an entrepreneur.
\end{abstract}

Contribution \& Value Added: This study is the first attempt that contributes to the field of social psychology and entrepreneurship by taking the entrepreneurial self-efficacy as a mediator and investigates the influence of entrepreneurial social identities (Darwinian, missionary, communitarian) on nascent entrepreneurial behaviour among students in Pakistan.

\begin{tabular}{|c|c|}
\hline Article type: & research article \\
\hline Keywords: & $\begin{array}{l}\text { entrepreneurial social identities; Darwinian; missionary; communitarian; entrepreneur- } \\
\text { ial self-efficacy; nascent entrepreneurial behaviour }\end{array}$ \\
\hline JEL codes: & L26, M13 \\
\hline Received: & Accepted: 15 July 2021 \\
\hline
\end{tabular}

Suggested citation:

Murad, M., Ashraf, S.F., Syed, N., Munir, M., \& Butt, R.S. (2022). Social identities and nascent entrepreneurial behaviour: Mediating role of entrepreneurial self-efficacy. Entrepreneurial Business and Economics Review, 10(1), 129-143. https://doi.org/10.15678/EBER.2022.100109

\section{INTRODUCTION}

Scholars around the world acknowledge the fact that entrepreneurship provides the freedom to individuals to start their businesses, fulfil their dreams, and satisfy needs to become entrepreneurs (Boudreaux et al., 2019). The association between an entrepreneur's identity and nascent entrepreneurial behaviour has received little attention in social psychology and entrepreneurship (Brändle et al., 2018; Lundqvist et al., 2015). Nascent entrepreneurial behaviour includes goal-oriented actions or decisions of an entrepreneur (Feng \& Chen, 2020). Falck et al. (2012) indicate that future researchers can incorporate the different entrepreneurial traits like attitudes and goals to predict entrepreneurial social identity's effects on nascent entrepreneurial behaviour. Several studies explain that entrepreneurial identity is an influential and vital factor in an entrepreneur's decisions and behaviours (Farmer et al., 2011; Hoang \& Gimeno, 
2010; Matlay et al., 2013). However, very limited research scrutinizes social identities in the context of entrepreneurship and nascent entrepreneurial behaviour (Alsos et al., 2016).

Various studies discuss the role of the theory of planned behaviour (Karimi, 2020) and the theory of alertness to examine entrepreneurial intentions and actions (Cai et al., 2021; Li, Murad, Shahzad, et al., 2020), and findings of these studies, not explain than the $35 \%$ of the total variance in entrepreneurial behavioural models (Li, Murad, Ashraf, et al., 2020; Neneh, 2019). Although there have been numerous studes of social identities, untouched grey areas linger (Brändle et al., 2018; Fauchart \& Gruber, 2011). Therefore, we should discuss the role of social identities in nascent entrepreneurial behaviour. The use of social identities assists the individuals in understanding and describing the heterogeneous actions used for starting a new business (Pan et al., 2019).

Hand et al. (2020) suggest that entrepreneurial self-efficacy plays a vital role in the field of entrepreneurship research (Multon et al., 1991). Therefore, individuals must experience entrepreneurial self-efficacy, which supports them to perform better in uncertain environment situations. Furthermore, several studies highlight the importance of entrepreneurial self-efficacy in the domain of entrepreneurship (de la Cruz et al., 2018; Gabrielsson \& Politis, 2011). Entrepreneurial self-efficacy defined as a judgment of one's ability to achieve a certain level of performance.

There are three types of entrepreneurial identities explained by prior researchers in the literature: Darwinian, missionary, and communitarian (de la Cruz et al., 2018; Fauchart \& Gruber, 2011). According to Khazami et al. (2020), the Darwinian identity refers to the classic business person, whose primary objective is to build a successful business and to focus on company growth. Missionary identity highlights the importance of social goals, in which a firm can play the role of an agent to change society (Brändle et al., 2018). Communitarian identity intensely encourages the individual forcefully with products or services (Alsos et al., 2016).

This study findings will enhance the existing literature from different perspectives. This study extends research on entrepreneurial social identities in the decision-making process and ways of handling nascent entrepreneurial behaviour (Brändle et al., 2018; Farmer et al., 2011). The analysis of this link may offer evidence on how specific entrepreneurial identity establishes a nascent entrepreneurial behaviour in its initial years (Alsos et al., 2016). Secondly, this study provides an extension to the empirical model (Fauchart \& Gruber, 2011) and contributes to the relationship between nascent entrepreneurial behaviour and entrepreneurial identity.

Furthermore, we advance the literature on entrepreneurial self-efficacy (Hand et al., 2020; Multon et al., 1991); as suggest Brändle et al. (2018), a few empirical studies highlight the indirect relationship between entrepreneurial identity and nascent entrepreneurial behaviour. Thirdly, building on survey data, the objective of this study was to identify the impact of social identities on how different entrepreneurial identities influence nascent entrepreneurial behaviour. Previous researchers do not test the relationship between entrepreneurial identity types and nascent entrepreneurial behaviour in the context of the Pakistani student sample. Thus, to fill this gap, this study is testing the empirical model to identify the influence of entrepreneurial social identities with the mediating role of entrepreneurial self-efficacy on nascent entrepreneurial behaviour. Furthermore, this study applied the structural equation modelling (SEM) technique to measure the student entrepreneurial behaviour.

The study proceeds as follows. The next section reviews the subject literature. The third section explains the materials and methods, while the fourth section describes the results and data analysis. The fifth section discusses findings, and the last section concludes the article with practical implications and limitations.

\section{LITERATURE REVIEW}

\section{Social Identities and Nascent Entrepreneurial Behaviour}

Social identities are associated with different types of entrepreneurial identities, which discuss the necessary social motivation of individuals and their self-evaluation to start a new business (Gruber \& MacMillan, 2017; Sieger et al., 2016). Researchers argue that social identity is gained from social 
memberships, and the individual describes him/herself as a social member of a group (Werthes et al., 2018). Fauchart and Gruber (2011) propose three types of social identities: Darwinian, missionary, and communitarian. These social identities come from the social identity theory, which engages in the making of social relationships among individuals in terms of personal and symbolic interaction (Hoang \& Gimeno, 2010).

The Darwinian identity describes the 'classic business person' whose primary objective is to start a strong, successful business (Alsos et al., 2016). An individual with a Darwinian identity focuses on assuring business success through strong ideas. Numerous scholars explain that entrepreneurs with a 'Darwinian identity' to focus on generating profit for the firm (de la Cruz et al., 2018). Moreover, Darwinian individuals have a professional approach and skills to manage their firms according to stable business ethics (Mmbaga et al., 2020). Thus, entrepreneurs with a Darwinian identity approach are more likely to establish profitable firms and achieve better performance. Therefore, we posit the following hypothesis:

H1a: Darwinian identity has a significant and positive effect on nascent entrepreneurial behaviour.

Missionary identity means an entrepreneur shows a strong belief own firm and work for a change in an aspect of society and community (Sieger et al., 2016). Scholars argue that missionary identity encourages building a cause and acting responsibly (Ashforth et al., 2008; Fauchart \& Gruber, 2011). Entrepreneurs with the missionary identity view their firms as platforms to pursue economic and societal goals (Wagenschwanz, 2021). Therefore, the missionary identity helps entrepreneurs improve the new business activities besides competition, which ultimately forms a significant role (Farmer et al., 2011). Based on the existing literature, we argue that social identity helps entrepreneurs to recognize and describe the heterogeneity of business behaviour in the formation of starting a new business venture and that venture orientation to its outcomes. Thus, the following hypothesis is suggested:

H1b: Missionary identity has a significant and positive effect on nascent entrepreneurial behaviour.

Communitarian identity means that an entrepreneur engages in the services and products that will contribute to the community and social activities (Sieger et al., 2016). Researchers explain that entrepreneurs with communitarian identities are usually engaged in community development (Alsos et al., 2016; Fauchart \& Gruber, 2011). Communitarian identity creates awareness among individuals through a product or activity and encourages different people to their ideas (Hoang \& Gimeno, 2010). Thus, entrepreneurs with a greater communitarian identity level are more likely to contribute to the community and its development. Based on this discussion, we propose:

H1c: Communitarian identity positively impacts nascent entrepreneurial behaviour.

\section{Social Identities and Entrepreneurial Self-Efficacy}

Darwinian identity is established in the free market economies. Therefore, it offers better chances to entrepreneurs with this identity to see environmental opportunities for their new business ventures (Mathias \& Williams, 2017). Brändle et al. (2018) suggest that Darwinian entrepreneurs need more motivation to develop their entrepreneurial self-efficacy. Farmer et al. (2011) explain that the higher the level of Darwinian identity, the less likely they are to experience negative emotions should they only work for their community. Thus, based on the discussion, we argue that individuals with Darwinian identity perceive a high level of entrepreneurial self-efficacy to become entrepreneurs and improve their business performance:

H2a: Darwinian identity has a significant and positive effect on entrepreneurial self-efficacy.

In turn, entrepreneurs with the missionary identity engage in improving community justice, preserving the natural environment, and developing the society into a better place to live (Żur, 2020). Researchers explain that missionary entrepreneurs are less likely to experience enactive mastery, in the beginning by establishing a process of their business ventures, and therefore may doubt the level of their entrepreneurial self-efficacy (Davidsson \& Honig, 2003). Prior studies argue that entrepreneurs who have a high level of missionary identity successfully change the world thanks to their 
better understating of society (Alsos et al., 2016; de la Cruz et al., 2018). Thus, based on this discussion, this study suggested that:

H2b: Missionary identity has a significant and positive effect on entrepreneurial self-efficacy.

Moreover, communitarian entrepreneurs can experience enactive mastery before they engage in the formation process because they use their prior knowledge to make a product or service (Hand et al., 2020). Communitarian entrepreneurs are responsible for the community and always work to better the community (Nielsen \& Lassen, 2012). Therefore, entrepreneurs with a low level of entrepreneurial self-efficacy have emotional anxiety and disappoint the group of people they identify with; on the other hand, entrepreneurs who have a high level of entrepreneurial self-efficacy are perceived as more prone to establish a social community. Thus, we posit that:

H2c: Communitarian identity positively impacts entrepreneurial self-efficacy.

\section{The Mediating Role of Entrepreneurial Self-Efficacy}

Entrepreneurial self-efficacy refers to an individual's beliefs regarding the ability to identify and exploit opportunities in the process of starting a new business (Hand et al., 2020). The indirect relationship between social identities and entrepreneurial self-efficacy on business performance was never empirically in the literature. Prior studies examine the direct influence of social identities on entrepreneurial self-efficacy and nascent entrepreneurial behaviour (Alsos et al., 2016; Brändle et al., 2018). Moreover, an entrepreneur's social identity affects the opportunities which identify, exploit, and evaluate decisions regarding firm performance (Fauchart \& Gruber, 2011). Thus, we posit that:

H3a: Entrepreneurial self-efficacy positively mediates the relationship between Darwinian identity and nascent entrepreneurial behaviour.

H3b: Entrepreneurial self-efficacy positively mediates the relationship between missionary identity and nascent entrepreneurial behaviour.

H3c: Entrepreneurial self-efficacy positively mediates the relationship between communitarian identity and nascent entrepreneurial behaviour.

\section{Entrepreneurial Self-Efficacy and Nascent Entrepreneurial Behaviour}

Entrepreneurial self-efficacy is the awareness of entrepreneurs' confidence in their abilities for starting a new business (Li, Murad, Shahzad, et al., 2020). Prior studies argue that entrepreneurial self-efficacy empirically links to nascent entrepreneurial behaviour (Alsos et al., 2016; Brändle et al., 2018). According to Gieure et al. (2020) entrepreneurial behaviour refers to the capacity or knowledge about a firm's constituent elements. According to the social learning theory, entrepreneurial self-efficacy can lead to task-specific outcomes (Barbosa et al., 2007). Entrepreneurs with entrepreneurial self-efficacy hold a strong belief in their skills to achieve tasks in entrepreneurial and performance domains (Drnovšek et al., 2010).

Furthermore, Sequeira et al. (2007) examined a survey study on entrepreneurial self-efficacy and nascent behaviour to find a positive and significant relationship. Similarly, Brändle et al. (2018) found that entrepreneurial self-efficacy strongly influences newly created business firms. Thus, the above suggest that entrepreneurs with more confidence in their abilities accomplish entrepreneurial activities and more skillfully lead their businesses to achieve maximum performance (Hechavarria et al., 2012; Hopp \& Stephan, 2012). Hence, we propose the following hypothesis:

H4: Entrepreneurial self-efficacy positively relates to nascent entrepreneurial behaviour.

Figure 1 below proposes the theoretical model in the study for social identities, entrepreneurial self-efficacy, and nascent entrepreneurial behaviour. 


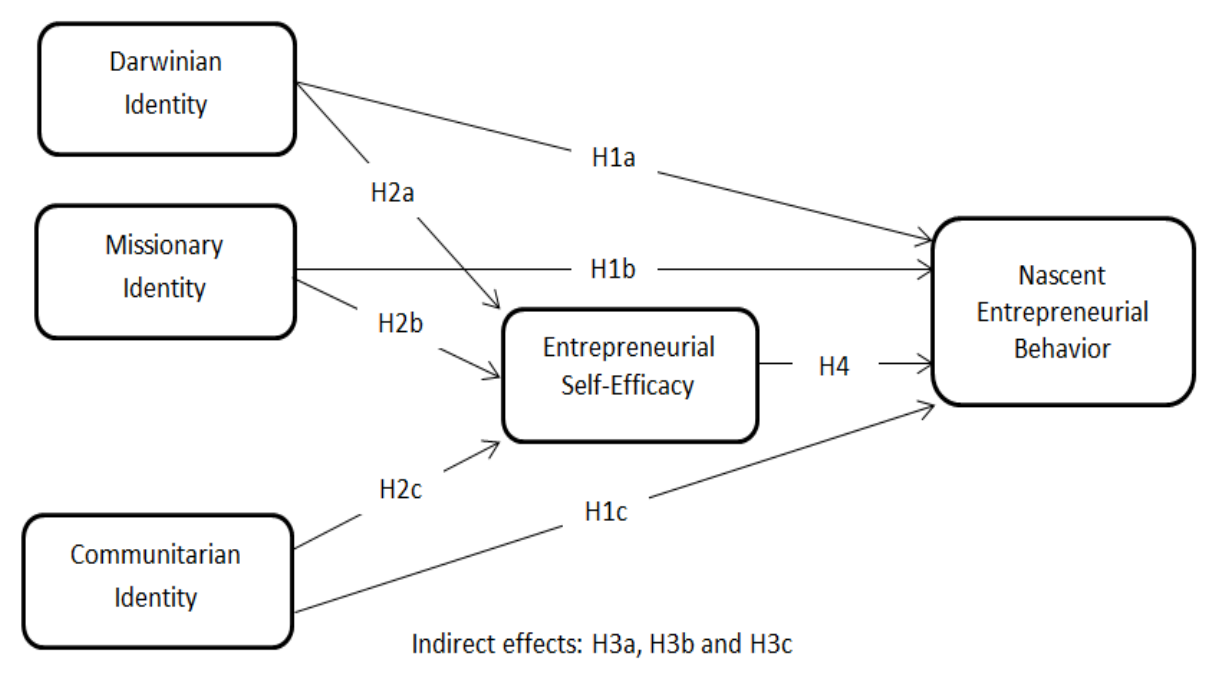

Figure 1. Conceptual model

Source: own elaboration.

\section{RESEARCH METHODOLOGY}

\section{Sample and Data Collection}

The data were retrieved from public sector university students in big cities of the province of Punjab in Pakistan: Faisalabad, Multan, and Lahore. These cities were selected because students from all over Punjab came there to complete their studies. The target population of the study were students of business, engineering, and IT departments. The total population of students was approximately 3200. According to Krejcie and Morgan (1970), if the study population exceeds 3000, the minimum sample size of 500 should suffice. Moreover, based on valid scales, we formulated a questionnaire for pilot testing 50 respondents from the mentioned communities.

The results of pilot testing were satisfactory. We assured respondents that the data they gave us will be only used for academic purposes. Furthermore, 550 paper-pencil surveys were distributed among students using a non-probability sampling technique. The original questionnaire was in the English language because in Pakistan English is the official teaching language in secondary and higher education, so the survey questions were written in English. A total of 455 responses were gathered with an $82.72 \%$ rate. Among the valid responses, 260 (57.1\%) were done by men and 195 (42.9\%) by women. The age ranged 18-40 years, and the most frequent age ranged 18-25 years (52.7\%). There were $44.4 \%$ undergraduate, $38.2 \%$ graduate, and $17.4 \%$ PhD students. Moreover, most students (34.7\%) belonged to business administration departments. Lastly, $57.1 \%$ of participants were interested in starting a new business.

\section{Measures}

\section{Darwinian Identity}

We assessed the Darwinian identity with five measurement items from previous research on social identities, using five-point Likert scales (Sieger et al., 2016). A sample item was 'I will create my firm in order to advance my career in the business world.'

\section{Communitarian Identity}

We used five items of the communitarian identity scale using five-point Likert anchors. This scale was developed and verified by prior researchers (Alsos et al., 2016; Sieger et al., 2016). A sample item was 'I will create my firm in order to play a proactive role in shaping the activities of a group of people with which I strongly identify.' 


\section{Missionary Identity}

To assess missionary identity, we applied five measurement items based on existing studies, using a five-point Likert scale (de la Cruz et al., 2018; Sieger et al., 2016). A sample item was 'I will create my firm in order to play a proactive role in changing how the world operates.'

\section{Entrepreneurial Self-Efficacy}

To measure entrepreneurial self-efficacy we applied four items on five-point Likert scales from previous research (Zhao et al., 2005). A sample item was 'I am convinced that I can successfully create new products.'

\section{Nascent Entrepreneurial Behavioural}

To assess nascent entrepreneurial behaviour, we used ten items on five-point Likert scales from a prior study (Li, Murad, Shahzad, et al., 2020). A sample item was 'I have written a business plan.'

\section{RESULTS AND DISCUSSION}

The results were analysed in the Smart-PLS software using partial least squares structural education modelling (PLS-SEM), which allows one to analyse direct and indirect mediation and moderation among constructs (Hair et al., 2011). This software is also known as the silver bullet for social science researchers (Asim et al., 2019; Hair et al., 2011; Ringle et al., 2020).

\section{Common Method Bias and Multi-Collinearity Issue}

We applied Harman's single factor test to check for the issue of common method bias in the data. The factor analysis findings indicated that the first factor explained $30.51 \%$ of the total variance, which was less than $50 \%$ of the total variance. Thus, there was no common method bias. Furthermore, a multicollinearity test was performed using the method suggested by Aiken et al. (1991), which posits that outer variance inflation factor (VIF) should be less than 5 (considered excellent). Thus, the values of VIF were shown in Table 1, and they indicated that all the values were acceptable and under the cut-off value of 5.

\section{Measurement Model}

For the measurement model analysis, reliability and validity tests were performed on the data. To assess the reliability of the constructs we used Cronbach's alpha ( $\alpha$ ) and composite reliability (CR). According to Henseler et al. (2015), the values of $(\alpha)$ should be $>0.70$, and the value of CR should be $>0.80$. As indicated in Table 1, the values for $(\alpha)$ and CR were higher than the threshold value of 0.70 . Moreover, convergent validity was also evaluated using the average variance extracted (AVE) values. Table 1 results showed that the values of AVE exceeded the cut-off value of 0.50 . Thus, this study achieved satisfactory results in reliability and validity analysis.

Table 1. Measurement model

\begin{tabular}{|c|c|c|c|c|c|}
\hline Constructs & $\begin{array}{l}\text { Load- } \\
\text { ings }\end{array}$ & $\begin{array}{l}\text { Cronbach's } \\
\text { Alpha (CA) }\end{array}$ & $\begin{array}{l}\text { Composite } \\
\text { Reliability } \\
\text { (CR) }\end{array}$ & $\begin{array}{l}\text { Average } \\
\text { Variance } \\
\text { Extracted } \\
\text { (AVE) }\end{array}$ & $\begin{array}{l}\text { Variance } \\
\text { Inflation } \\
\text { Factors } \\
\text { (VIF) }\end{array}$ \\
\hline Darwinian Identity & & 0.925 & 0.944 & 0.771 & \\
\hline $\begin{array}{l}\text { DAR 1: I will create my firm in order to advance my ca- } \\
\text { reer in the business world. }\end{array}$ & 0.942 & & & & 4.888 \\
\hline $\begin{array}{l}\text { DAR 2: As a firm founder, it will be very important to me } \\
\text { to operate my firm on the basis of solid management } \\
\text { practices. }\end{array}$ & 0.925 & & & & 4.741 \\
\hline $\begin{array}{l}\text { DAR 3: As a firm founder, it will be very important to me } \\
\text { to have thoroughly analysed the financial prospects of } \\
\text { my business. }\end{array}$ & 0.911 & & & & 4.003 \\
\hline
\end{tabular}




\begin{tabular}{|c|c|c|c|c|c|}
\hline Constructs & $\begin{array}{l}\text { Load- } \\
\text { ings }\end{array}$ & $\begin{array}{l}\text { Cronbach's } \\
\text { Alpha (CA) }\end{array}$ & $\begin{array}{l}\text { Composite } \\
\text { Reliability } \\
\text { (CR) }\end{array}$ & $\begin{array}{c}\text { Average } \\
\text { Variance } \\
\text { Extracted } \\
\text { (AVE) }\end{array}$ & $\begin{array}{l}\text { Variance } \\
\text { Inflation } \\
\text { Factors } \\
\text { (VIF) }\end{array}$ \\
\hline $\begin{array}{l}\text { DAR 4: When managing my firm, it will be very im- } \\
\text { portant to me to have a strong focus on what my firm } \\
\text { can achieve vis-à-vis the competition. }\end{array}$ & 0.864 & & & & 2.721 \\
\hline $\begin{array}{l}\text { DAR 5: When managing my firm, it will be very important } \\
\text { to me to establish a strong competitive advantage and } \\
\text { significantly outperform other firms in my domain. }\end{array}$ & 0.912 & & & & 4.038 \\
\hline Missionary Identity & & 0.930 & 0.947 & 0.783 & \\
\hline $\begin{array}{l}\text { MIS 1: I will create my firm in order to play a proactive } \\
\text { role in changing how the world operates. }\end{array}$ & 0.835 & & & & 2.205 \\
\hline $\begin{array}{l}\text { MIS 2: As a firm founder, it will be very important to me } \\
\text { to be a highly responsible citizen of our world. }\end{array}$ & 0.857 & & & & 2.524 \\
\hline $\begin{array}{l}\text { MIS 3: As a firm founder, it will be very important to me } \\
\text { to make the world a 'better place' (e.g. by pursuing so- } \\
\text { cial justice, protecting the environment). }\end{array}$ & 0.916 & & & & 4.515 \\
\hline $\begin{array}{l}\text { MIS 4: When managing my firm, it will be very important } \\
\text { to me to have a strong focus on what the firm is able to } \\
\text { achieve for society-at-large. }\end{array}$ & 0.906 & & & & 4.075 \\
\hline $\begin{array}{l}\text { MIS 5: When managing my firm, it will be very important to } \\
\text { me to convince others that private firms are indeed able to } \\
\text { address the type of societal challenges that my firm ad- } \\
\text { dresses (e.g. social justice, environmental protection). }\end{array}$ & 0.908 & & & & 4.096 \\
\hline Communitarian Identity & & 0.925 & 0.944 & 0.771 & \\
\hline $\begin{array}{l}\text { COM 1: I will create my firm in order to solve a specific } \\
\text { problem for a group of people that I strongly identify } \\
\text { with (e.g. friends, colleagues, club, community). }\end{array}$ & 0.851 & & & & 2.640 \\
\hline $\begin{array}{l}\text { COM 2: I will create my firm in order to play a proactive } \\
\text { role in shaping the activities of a group of people that I } \\
\text { strongly identify with. }\end{array}$ & 0.818 & & & & 2.432 \\
\hline $\begin{array}{l}\text { COM 3: As a firm founder, it will be very important to } \\
\text { me to provide a product/service that is useful to a group } \\
\text { of people that I strongly identify with (e.g. friends, col- } \\
\text { leagues, club, community). }\end{array}$ & 0.876 & & & & 2.986 \\
\hline $\begin{array}{l}\text { COM 4: When managing my firm, it will be very im- } \\
\text { portant to me to have a strong focus on a group of peo- } \\
\text { ple that I strongly identify with (e.g. friends, colleagues, } \\
\text { club, community). }\end{array}$ & 0.929 & & & & 4.512 \\
\hline $\begin{array}{l}\text { COM 5: When managing my firm, it will be very im- } \\
\text { portant to me to support and advance a group of people } \\
\text { that I strongly identify with (e.g. friends, colleagues, } \\
\text { club, community). }\end{array}$ & 0.913 & & & & 4.167 \\
\hline \begin{tabular}{|l|} 
Entrepreneurial Self-Efficacy \\
\end{tabular} & & 0.934 & 0.953 & 0.834 & \\
\hline $\begin{array}{l}\text { ESE 1: I am convinced that I can successfully discover } \\
\text { new business opportunities. }\end{array}$ & 0.910 & & & & 3.459 \\
\hline $\begin{array}{l}\text { ESE 2: I am convinced that I can successfully create new } \\
\text { products. }\end{array}$ & 0.893 & & & & 3.108 \\
\hline ESE 3: I am convinced that I can think creatively. & 0.920 & & & & 5.673 \\
\hline $\begin{array}{l}\text { ESE 4: I am convinced that I can successfully commer- } \\
\text { cialize ideas. }\end{array}$ & 0.929 & & & & 4.116 \\
\hline Nascent Entrepreneurial Behaviour & & 0.937 & 0.946 & 0.639 & \\
\hline
\end{tabular}




\begin{tabular}{|l|c|l|l|c|c|}
\hline \multicolumn{1}{|c|}{ Constructs } & $\begin{array}{c}\text { Load- } \\
\text { ings }\end{array}$ & $\begin{array}{c}\text { Cronbach's } \\
\text { Alpha (CA) }\end{array}$ & $\begin{array}{c}\text { Composite } \\
\text { Reliability } \\
\text { (CR) }\end{array}$ & $\begin{array}{c}\text { Average } \\
\text { Variance } \\
\text { Extracted } \\
\text { (AVE) }\end{array}$ & $\begin{array}{c}\text { Variance } \\
\text { Inflation } \\
\text { Factors } \\
\text { (VIF) }\end{array}$ \\
\hline $\begin{array}{l}\text { NEB 1: I have discussed a product or business idea with } \\
\text { potential customers. }\end{array}$ & 0.745 & & & & 2.157 \\
\hline $\begin{array}{l}\text { NEB 2: I have collected information about markets and } \\
\text { competitors. }\end{array}$ & 0.772 & & & & 2.681 \\
\hline NEB 3: I have written a business plan. & 0.804 & & & & 3.098 \\
\hline NEB 4: I have started product/service development. & 0.830 & & & & 2.670 \\
\hline NEB 5: I have started marketing or promotion efforts. & 0.801 & & & & 2.051 \\
\hline $\begin{array}{l}\text { NEB 6: I have purchased material, equipment, or ma- } \\
\text { chinery for the business. }\end{array}$ & 0.750 & & & & 3.083 \\
\hline NEB 7: I attempted to obtain external funding. & 0.826 & & & & 3.361 \\
\hline $\begin{array}{l}\text { NEB 8: I have applied for a patent, copyright, or trade- } \\
\text { mark. }\end{array}$ & 0.859 & & & & 2.796 \\
\hline NEB 9: I have registered the company. & 0.834 & & & & 2.146 \\
\hline NEB 10: I have sold product or service. & 0.765 & & & & 2.539 \\
\hline
\end{tabular}

Note: DAR= Darwinian Identity, MIS= Missionary Identity, COM= Communitarian Identity, ESE= Entrepreneurial Self-Efficacy, NEB= Nascent Entrepreneurial Behaviour.

Source: own study.

Moreover, to assess the discriminant validity, we used widely accepted criteria of Fornell and Larcker (1981) and Heterotrait-Monotrait Ratio HTMT. The results of the discriminant validity were shown in Tables 2 and 3. As per Henseler et al.'s (2015) criteria, square root of the average variance extracted (AVE) is called discriminant validity, and the values under the AVE were correlations. According to Henseler et al. (2015), the criteria values of HTMT should be less than 0.85 . Thus, as we observed that the maximum achieved HTMT value was 0.507 , all the constructs were meeting the standard for discriminant validity.

Table 2. Fornell-Larcker criterion

\begin{tabular}{|c|c|c|c|c|c|}
\hline Variables & COM & DAR & ESE & MIS & NEB \\
\hline COM & $\mathbf{0 . 8 7 8}$ & & & & \\
\hline DAR & $0.374^{* * *}$ & $\mathbf{0 . 9 1 1}$ & & & \\
\hline ESE & $0.409^{* * *}$ & $0.478^{* * *}$ & $\mathbf{0 . 9 1 3}$ & & \\
\hline MIS & $0.311^{* * *}$ & $0.404^{* * *}$ & $0.383^{* * *}$ & $\mathbf{0 . 8 8 5}$ & \\
\hline NEB & $0.382^{* * *}$ & $0.392^{* * *}$ & $0.460^{* * *}$ & $0.419^{* * *}$ & $\mathbf{0 . 7 9 9}$ \\
\hline
\end{tabular}

$* * *$ Significant $(p<0.001)$.

Note: DAR= Darwinian Identity, MIS= Missionary Identity, COM= Communitarian Identity, ESE= Entrepreneurial Self-Efficacy, NEB= Nascent Entrepreneurial Behaviour. Values with diagonal are the square root of the average variance extracted (AVE). Values under diagonals are correlations.

Source: own study.

Table 3. Heterotrait-monotrait ratio (HTMT)

\begin{tabular}{|c|c|c|c|c|c|}
\hline Variables & COM & DAR & ESE & MIS & NEB \\
\hline COM & & & & & \\
\hline DAR & 0.398 & & & & \\
\hline ESE & 0.437 & 0.507 & & & \\
\hline MIS & 0.334 & 0.427 & 0.410 & & \\
\hline NEB & 0.401 & 0.413 & 0.488 & 0.447 & \\
\hline
\end{tabular}

Note: $\mathrm{DAR}=$ Darwinian Identity, MIS= Missionary Identity, COM= Communitarian Identity, ESE= Entrepreneurial Self-Efficacy, NEB = Nascent Entrepreneurial Behaviour.

Source: own study. 


\section{Structural Model}

The structural model was analysed using the 5000 bootstrapping method with the help of the SmartPLS software. The fitness of the structural model was assessed by the standardized root mean square residual (SRMR) value. According to Henseler et al. (2015), a good model must have a $<0.08$ value of SRMR. As the result of the structural model SRMR was 0.045 , our model proved absolute fitness. Moreover, to assess the values of $R^{2}$ and $Q^{2}$ we used the recommendation by Chin (1998) regarding the desired $R^{2}$ and $Q^{2}$ values, which should be greater than 0.1 or zero. In Figure 2 and Table 4 , structural model results show that all the values of $R^{2}$ and $Q^{2}$ were acceptable and exceeded the suggested benchmark of 0.1 . Furthermore, the values of $\mathrm{R}^{2}$ explained a $31.7 \%$ variance in entrepreneurial selfefficacy and $31.9 \%$ in nascent entrepreneurial behaviour. According to the existing research findings, studies on entrepreneurial intention-behaviour models explained only 10-30\% variance in the structural model analysis (Li, Murad, Ashraf, et al., 2020; Li, Murad, Shahzad, et al., 2020; Neneh, 2019).

Table 4. $\mathbf{R}^{2}$ and $\mathbf{Q}^{2}$

\begin{tabular}{|c|c|c|}
\hline Variables & R Square & $\mathbf{Q}^{\mathbf{2}}$ \\
\hline ESE & 0.317 & 0.175 \\
\hline NEB & 0.319 & 0.221 \\
\hline
\end{tabular}

Note: ESE= Entrepreneurial Self-Efficacy, NEB= Nascent Entrepreneurial Behaviour.

Source: own study.

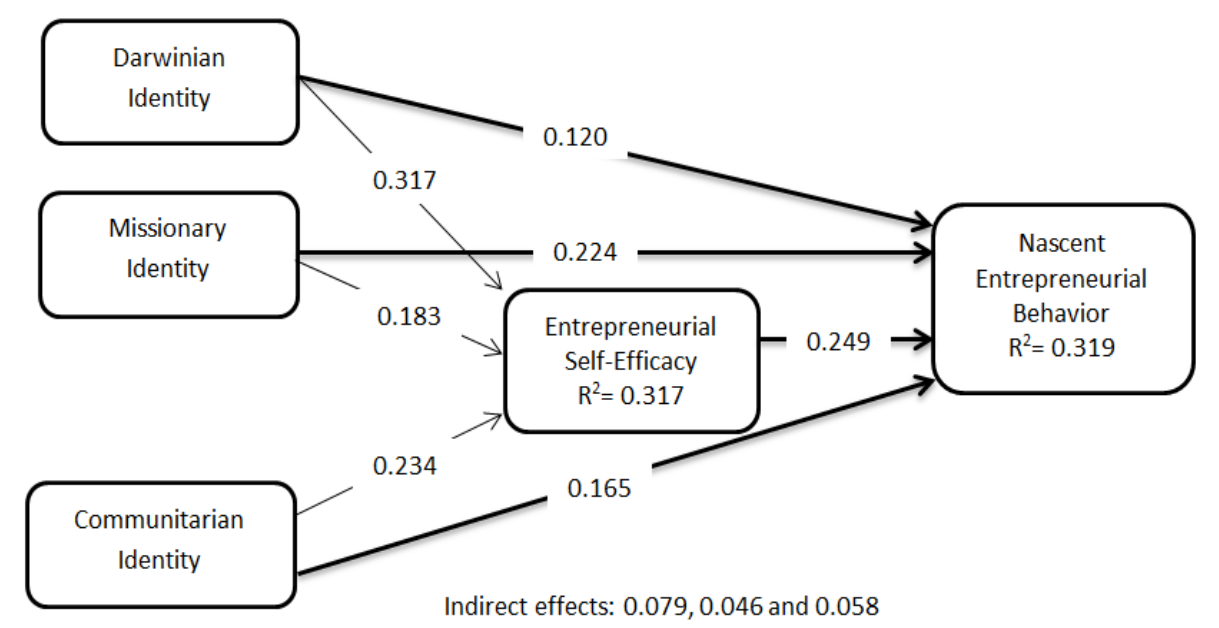

Figure 1. Structural model

Source: own elaboration.

Furthermore, the results of all hypotheses were positively and significantly related to the nascent entrepreneurial behaviour model. The significant results of bootstrapping were shown in Table 5 . The findings of $\mathrm{H} 1 \mathrm{a}, \mathrm{H} 1 \mathrm{~b}$, and $\mathrm{H} 1 \mathrm{c}$ showed that Darwinian, communitarian, and missionary social identities have a positive and significant influence on nascent entrepreneurial behavioural (Darwinian $\beta=0.120$, $\mathrm{t}=2.467, p=0.014$; missionary $\beta=0.224, \mathrm{t}=5.300, p=0.000$; communitarian $\beta=0.165, \mathrm{t}=3.328, p=0.001$ ). Therefore, $\mathrm{H} 1 \mathrm{a}, \mathrm{H} 1 \mathrm{~b}$, and $\mathrm{H} 1 \mathrm{c}$ were accepted. Moreover, the results of $\mathrm{H} 2 \mathrm{a}, \mathrm{H} 2 \mathrm{~b}$, and $\mathrm{H} 2 \mathrm{c}$ indicated that Darwinian, communitarian, and missionary social identities have a positive and significant impact on entrepreneurial self-efficacy (Darwinian $\beta=0.317, t=5.800, p=0.000$; missionary $\beta=0.183, t=4.355$, $p=0.000$; communitarian $\beta=0.234, \mathrm{t}=4.417, p=0.000$ ). Hence, $\mathrm{H} 2 \mathrm{a}, \mathrm{H} 2 \mathrm{~b}$, and $\mathrm{H} 2 \mathrm{c}$ were supported. Furthermore, the findings of $\mathrm{H} 4$ revealed that entrepreneurial self-efficacy has a positive and significant effect on nascent entrepreneurial behaviour $(\beta=0.249, \mathrm{t}=4.146, p=0.000)$. Thus, $\mathrm{H} 4$ was supported.

To assess the indirect effects regarding hypotheses $\mathrm{H} 3 \mathrm{a}, \mathrm{H} 3 \mathrm{~b}$, and $\mathrm{H} 3 \mathrm{c}$, we predicted that entrepreneurial self-efficacy mediates in the relationship between Darwinian, communitarian, missionary identities, along with nascent entrepreneurial behaviour. Table 6 findings show that entrepreneurial self-effi- 
cacy has positive and significant indirect effects on Darwinian identity ( $\beta=0.079, \mathrm{t}=3.045, p=0.002)$, missionary identity $(\beta=0.046, \mathrm{t}=2.813, p=0.005)$, and communitarian identity $(\beta=0.058, \mathrm{t}=3.151, p=0.002)$, along with nascent entrepreneurial behaviour. Furthermore, to evaluate the full/partial mediation effects, we followed variance accounted for (VAF) criteria suggested by Sarstedt et al. (2017). According to these criteria, if the value of $\mathrm{VAF}$ is $>0.10$ and $<0.80$, it explains the partial mediation, and if the value of VAF is $>0.80$, it shows full mediation. Table 7 indicated that the values of VAF were $>0.10$ and $<0.80$, hence representing partial mediation effects. Accordingly, $\mathrm{H} 3 \mathrm{a}, \mathrm{H} 3 \mathrm{~b}$, and $\mathrm{H} 3 \mathrm{c}$ were also accepted.

Table 5. Direct effects

\begin{tabular}{|c|c|c|c|c|}
\hline Hypotheses & Relationships & $\boldsymbol{\beta}$ & $\mathbf{t}$ & $\boldsymbol{p}$ \\
\hline H1a & DAR -> NEB & 0.120 & 2.467 & 0.014 \\
\hline H1b & MIS -> NEB & 0.224 & 5.300 & 0.000 \\
\hline H1c & COM -> NEB & 0.165 & 3.328 & 0.001 \\
\hline H2a & DAR -> ESE & 0.317 & 5.800 & 0.000 \\
\hline H2b & MIS -> ESE & 0.183 & 4.355 & 0.000 \\
\hline H2c & COM -> ESE & 0.234 & 4.417 & 0.000 \\
\hline H4 & ESE -> NEB & 0.249 & 4.146 & 0.000 \\
\hline
\end{tabular}

$* * *$ Significant $(p<0.001)$.

Note: DAR= Darwinian Identity, MIS= Missionary Identity, COM= Communitarian Identity, ESE= Entrepreneurial Self-Efficacy, NEB= Nascent Entrepreneurial Behaviour.

Source: own study.

Table 6. Indirect effects and mediation analysis

\begin{tabular}{|c|c|c|c|c|}
\hline Hypotheses & Relationships & $\boldsymbol{\beta}$ & $\mathbf{t}$ & $\boldsymbol{p}$ \\
\hline H3a & DAR -> ESE -> NEB & 0.079 & 3.045 & 0.002 \\
\hline H3b & MIS -> ESE -> NEB & 0.046 & 2.813 & 0.005 \\
\hline H3c & COM -> ESE -> NEB & 0.058 & 3.045 & 0.002 \\
\hline
\end{tabular}

*** Significant $(p<0.001)$.

Note: $\mathrm{DAR}=$ Darwinian Identity, MIS= Missionary Identity, $\mathrm{COM}=$ Communitarian Identity, ESE= Entrepreneurial Self-Efficacy, NEB= Nascent Entrepreneurial Behaviour.

Source: own study.

Table 7. Mediation analysis (ESE as mediator)

\begin{tabular}{|c|c|c|c|c|c|c|}
\hline $\begin{array}{c}\text { Independent } \\
\text { Variables }\end{array}$ & $\begin{array}{c}\text { Direct } \\
\text { Effects }\end{array}$ & $\begin{array}{c}\text { Indirect } \\
\text { Effects }\end{array}$ & Total Effects & VAF Range & Mediation & $\begin{array}{c}\text { Dependent } \\
\text { Variable }\end{array}$ \\
\hline DIS & 0.120 & 0.079 & 0.199 & $39 \%$ & Partial Mediation & NES \\
\hline MIS & 0.224 & 0.046 & 0.270 & $17 \%$ & Partial Mediation & NES \\
\hline COM & 0.165 & 0.058 & 0.223 & $26 \%$ & Partial Mediation & NES \\
\hline
\end{tabular}

Note: DAR= Darwinian Identity, MIS= Missionary Identity, COM= Communitarian Identity, ESE= Entrepreneurial Self-Efficacy, NEB= Nascent Entrepreneurial Behaviour.

Source: own study.

\section{Discussion}

This study offers a significant contribution in the field of social psychology and entrepreneurship. Firstly, this study identifies the role of an entrepreneur's social identity on nascent entrepreneurial behaviour and confirms that each entrepreneur's social identity has a positive and significant influence on nascent entrepreneurial behaviour. Secondly, the study findings indicate that entrepreneurial self-efficacy is a positive driver of social identity and translates entrepreneurial actions into reality. Moreover, the results show that Darwinian, communitarian, and missionary identities have a positive and significant influence on entrepreneurial self-efficacy and nascent entrepreneurial behaviour. This result agrees with prior studies on social identities and entrepreneurship in the context of Asian and European studies (Brändle et al., 2018; Crudu, 2019; Hand et al., 2020). According to Fauchart and Gruber (2011), Darwinian, communitarian, and missionary identities play an important role in the development of new business ventures, and entrepreneurs with a high level of social 
identities are more likely to establish a strong and successful business by providing an authentic product and services to their communities (Zygmunt, 2018).

Furthermore, our findings indicate that entrepreneurial self-efficacy has a positive and significant effect on nascent entrepreneurial behaviour. This result is consistent with existing literature (Drnovšek et al., 2010; Schmutzler et al., 2019), which finds that entrepreneurs with a high level of entrepreneurial self-efficacy are more likely to perform a certain level of tasks and are more interested in starting new businesses. Moreover, our findings show that entrepreneurial self-efficacy partially mediates the relationship between social identities and nascent entrepreneurial behaviour. This result allows us to conclude that entrepreneurs with Darwinian, communitarian, and missionary identities start by using entrepreneurial self-efficacy in decisions related to new business development processes. Moreover, our results broaden the entrepreneurial self-efficacy literature by investigating how nascent entrepreneurs' association with social identities influences their self-efficacy. Without entrepreneurial self-efficacy, individuals do not motivate stronger perceptions of entrepreneurial action. Several studies argue that individuals with a high level of self-efficacy are more active and inclined to pursue a career in entrepreneurship (Hopp \& Stephan, 2012; Obschonka et al., 2015). However, entrepreneurs with Darwinian, communitarian, and missionary identities are more likely to feel capable of their entrepreneurial abilities. Entrepreneurs with a low level of entrepreneurial self-efficacy are less competent to handle community issues in order to make the world a 'better place.'

\section{CONCLUSIONS}

This study examines the influence that entrepreneurial social identities - Darwinian, communitarian, and missionary - have on nascent entrepreneurial behaviour, with the mediating role of entrepreneurial self-efficacy. This study contributes to the field of social psychology and entrepreneurship. The findings show that Darwinian, missionary, and communitarian identities have a positive and significant impact on entrepreneurial self-efficacy and nascent entrepreneurial behaviour. Several studies argue that entrepreneurial social identity is an important factor in entrepreneurs' actions (Alsos et al., 2016; de la Cruz et al., 2018), and limited empirical studies tackle social identity in the context of nascent entrepreneurial behaviour among students. Therefore, this study specifically focuses on the nascent entrepreneurial behaviour of students who want to become entrepreneurs through employing entrepreneurial social identities.

This study offers practical implications for researchers, practitioners, and educationalists. Firstly, our results show the importance of identifying the differences in entrepreneurs' goals linked to new business development. These differences indicate that policy-makers and advisors pursuing high-quality new firms should not assume that all entrepreneurs are generally encouraged by profits and behave accordingly. Instead, the structure for motivating entrepreneurs varies depending on the situation. Therefore, the actions for entrepreneurial setup are the most rational activity that depends on the social identity of the entrepreneurs containing him/her motives. Secondly, our findings enable us to suggest future outlines of training in entrepreneurship that foster the use of social identities in decision-making and new firm development. Entrepreneurial self-efficacy might be considered a means for developing entrepreneurial intentions among entrepreneurs, but also for attaining maximum business growth.

Moreover, our study might enhance the willpower of each type of social identity to think and take action so as to forest preeminent behaviours and accomplish goals. Thirdly, several literature studies offer implications for conducting training programs on supporting entrepreneurs to develop their new business concepts and related business strategies. However, entrepreneurial social identity is such a significant element in the entrepreneurial process that platforms would take advantage from attending more to identifying potential entrepreneurs by entrepreneurial social identities and searching for their authentic entrepreneurial identities - such as Darwinian, communitarian, and missionary - in unison with the idea and business development process for an individual to pursue a career in entrepreneurship.

This study has several limitations. Firstly, this study's nature is cross-sectional ass data was gathered using a self-administered survey from the public sector universities of Punjab, Pakistan, with a low sample 
size. We suggest that future researchers conduct longitudinal research on entrepreneurial social identities and causation processes to examine entrepreneurial/firm performance. Secondly, our results are based on the idea of Fauchart and Gruber (2011) who use three social entrepreneurial identities - Darwinian, communitarian, and missionary - which representing only one way of distinguishing between different identity types. Future research might consider hybrid identities to investigate nascent behaviour and firm performance. Thirdly, we found that the three social identities had a significant impact on nascent entrepreneurial behaviour. Thus, future research should examine the influence of role identity, human entrepreneurial identity, and family business identity on nascent entrepreneurial behaviour.

\section{REFERENCES}

Aiken, L. S., West, S. G., \& Reno, R. R. (1991). Multiple regression: Testing and interpreting interactions. Sage.

Alsos, G. A., Clausen, T. H., Hytti, U., \& Solvoll, S. (2016). Entrepreneurs' social identity and the preference of causal and effectual behaviours in start-up processes. Entrepreneurship and Regional Development, 28(3-4), $234-258$.

Ashforth, B. E., Harrison, S. H., \& Corley, K. G. (2008). Identification in organizations: An examination of four fundamental questions. Journal of Management, 34(3), 325-374.

Asim, S., Li, C., Makhdoom, H. U. R., \& Zafar, Z. (2019). Entrepreneurial Technology Opportunism and Its Impact on Business Sustainability with the Moderation of Government Regulations. Entrepreneurial Business and Economics Review, 7, 161-185.

Barbosa, S. D., Gerhardt, M. W., \& Kickul, J. R. (2007). The role of cognitive style and risk preference on entrepreneurial self-efficacy and entrepreneurial intentions. Journal of Leadership and Organizational Studies, 13(4), 86-104.

Boudreaux, C. J., Nikolaev, B. N., \& Klein, P. (2019). Socio-cognitive traits and entrepreneurship: The moderating role of economic institutions. Journal of Business Venturing, 34(1), 178-196.

Brändle, L., Berger, E. S., Golla, S., \& Kuckertz, A. (2018). I am what I am-How nascent entrepreneurs' social identity affects their entrepreneurial self-efficacy. Journal of Business Venturing Insights, 9, 17-23.

Cai, L., Murad, M., Ashraf, S. F., \& Naz, S. (2021). Impact of dark tetrad personality traits on nascent entrepreneurial behavior: the mediating role of entrepreneurial intention. Frontiers of Business Research in China, 15(1), 1-19.

Chin, W. W. (1998). The partial least squares approach to structural equation modeling. Modern Methods for Business Research, 295(2), 295-336.

Crudu, R. (2019). The role of innovative entrepreneurship in the economic development of EU member countries. Journal of Entrepreneurship, Management and Innovation, 15(1), 35-60.

Davidsson, P., \& Honig, B. (2003). The role of social and human capital among nascent entrepreneurs. Journal of Business Venturing, 18(3), 301-331.

de la Cruz, M. E., Jover, A. J. V., \& Gras, J. M. G. (2018). Influence of the entrepreneur's social identity on business performance through effectuation. European Research on Management and Business Economics, 24(2), 90-96.

Drnovšek, M., Wincent, J., \& Cardon, M. S. (2010). Entrepreneurial self-efficacy and business start-up: developing a multi-dimensional definition. International Journal of Entrepreneurial Behavior and Research, 16(4), 329-348.

Falck, O., Heblich, S., \& Luedemann, E. (2012). Identity and entrepreneurship: do school peers shape entrepreneurial intentions? Small Business Economics, 39(1), 39-59.

Farmer, S. M., Yao, X., \& Kung-Mcintyre, K. (2011). The behavioral impact of entrepreneur identity aspiration and prior entrepreneurial experience. Entrepreneurship Theory and Practice, 35(2), 245-273.

Fauchart, E., \& Gruber, M. (2011). Darwinians, communitarians, and missionaries: The role of founder identity in entrepreneurship. Academy of Management Journal, 54(5), 935-957.

Feng, B., \& Chen, M. (2020). The impact of entrepreneurial passion on psychology and behavior of entrepreneurs. Frontiers in Psychology, 11, 1733.

Fornell, C., \& Larcker, D. F. (1981). Evaluating structural equation models with unobservable variables and measurement error. Journal of Marketing Research, 18(1), 39-50.

Gabrielsson, J., \& Politis, D. (2011). Career motives and entrepreneurial decision-making: examining preferences for causal and effectual logics in the early stage of new ventures. Small Business Economics, 36(3), 281-298. 
Gieure, C., del Mar Benavides-Espinosa, M., \& Roig-Dobón, S. (2020). The entrepreneurial process: The link between intentions and behavior. Journal of Business Research, 112, 541-548.

Gruber, M., \& MacMillan, I. C. (2017). Entrepreneurial behavior: A reconceptualization and extension based on identity theory. Strategic Entrepreneurship Journal, 11(3), 271-286.

Hair, J., Ringle, C., \& Sarstedt, M. (2011). PLS-SEM: Indeed a silver bullet. Journal of Marketing Theory and Practice, 19(2), 139-152.

Hand, C., Iskandarova, M., \& Blackburn, R. (2020). Founders' social identity and entrepreneurial self-efficacy amongst nascent entrepreneurs: A configurational perspective. Journal of Business Venturing Insights, 13(C).

Hechavarria, D. M., Renko, M., \& Matthews, C. H. (2012). The nascent entrepreneurship hub: goals, entrepreneurial self-efficacy and start-up outcomes. Small Business Economics, 39(3), 685-701.

Henseler, J., Ringle, C. M., \& Sarstedt, M. (2015). A new criterion for assessing discriminant validity in variancebased structural equation modeling. Journal of the Academy of Marketing Science, 43(1), 115-135.

Hoang, H., \& Gimeno, J. (2010). Becoming a founder: How founder role identity affects entrepreneurial transitions and persistence in founding. Journal of Business Venturing, 25(1), 41-53.

Hopp, C., \& Stephan, U. (2012). The influence of socio-cultural environments on the performance of nascent entrepreneurs: Community culture, motivation, self-efficacy and start-up success. Entrepreneurship and Regional Development, 24(9-10), 917-945.

Karimi, S. (2020). The role of entrepreneurial passion in the formation of students' entrepreneurial intentions. Applied Economics, 52(3), 331-344.

Khazami, N., Nefzi, A., \& Jaouadi, M. (2020). The effect of social capital on the development of the social identity of agritourist entrepreneur: A qualitative approach. Cogent Social Sciences, 6(1), 1787680.

Krejcie, R. V., \& Morgan, D. W. (1970). Determining sample size for research activities. Educational and Psychological Measurement, 30(3), 607-610.

Li, C., Murad, M., Ashraf, S. F., Syed, N., \& Riaz, M. (2020). Entrepreneurial nascent behaviour: The role of causation process in opportunity discovery and creation. Entrepreneurial Business and Economics Review, 8(4), 183-200.

Li, C., Murad, M., Shahzad, F., Khan, M. A. S., Ashraf, S. F., \& Dogbe, C. S. K. (2020). Entrepreneurial passion to entrepreneurial behavior: role of entrepreneurial alertness, entrepreneurial self-efficacy and proactive personality. Frontiers in Psychology, 11, 01611.

Lundqvist, M., Middleton, K. W., \& Nowell, P. (2015). Entrepreneurial identity and role expectations in nascent entrepreneurship. Industry and Higher Education, 29(5), 327-344.

Mathias, B. D., \& Williams, D. W. (2017). The impact of role identities on entrepreneurs' evaluation and selection of opportunities. Journal of Management, 43(3), 892-918.

Matlay, H., Hytti, U., \& Heinonen, J. (2013). Heroic and humane entrepreneurs: identity work in entrepreneurship education. Education+ Training, 55(8/9), 886-898.

Mmbaga, N. A., Mathias, B. D., Williams, D. W., \& Cardon, M. S. (2020). A review of and future agenda for research on identity in entrepreneurship. Journal of Business Venturing, 35(6), 106049.

Multon, K. D., Brown, S. D., \& Lent, R. W. (1991). Relation of self-efficacy beliefs to academic outcomes: A metaanalytic investigation. Journal of Counseling Psychology, 38(1), 30.

Neneh, B. N. (2019). From entrepreneurial alertness to entrepreneurial behavior: The role of trait competitiveness and proactive personality. Personality and Individual Differences, 138, 273-279.

Nielsen, S. L., \& Lassen, A. H. (2012). Identity in entrepreneurship effectuation theory: a supplementary framework. International Entrepreneurship and Management Journal, 8(3), 373-389.

Obschonka, M., Silbereisen, R. K., Cantner, U., \& Goethner, M. (2015). Entrepreneurial self-identity: predictors and effects within the theory of planned behavior framework. Journal of Business and Psychology, 30(4), 773-794.

Pan, N. D., Gruber, M., \& Binder, J. (2019). Painting with all the colors: The value of social identity theory for understanding social entrepreneurship. Academy of Management Review, 44(1), 213-215.

Ringle, C. M., Sarstedt, M., Mitchell, R., \& Gudergan, S. P. (2020). Partial least squares structural equation modeling in HRM research. The International Journal of Human Resource Management, 31(12), 1617-1643.

Sarstedt, M., Ringle, C. M., \& Hair, J. F. (2017). Partial least squares structural equation modeling. Handbook of Market Research, 26(1), 1-40. 
Schmutzler, J., Andonova, V., \& Diaz-Serrano, L. (2019). How context shapes entrepreneurial self-efficacy as a driver of entrepreneurial intentions: A multilevel approach. Entrepreneurship Theory and Practice, 43(5), 880-920.

Sequeira, J., Mueller, S. L., \& McGee, J. E. (2007). The influence of social ties and self-efficacy in forming entrepreneurial intentions and motivating nascent behavior. Journal of Developmental Entrepreneurship, 12(03), 275-293.

Sieger, P., Gruber, M., Fauchart, E., \& Zellweger, T. (2016). Measuring the social identity of entrepreneurs: Scale development and international validation. Journal of Business Venturing, 31(5), 542-572.

Wagenschwanz, A. M. (2021). The Identity of Entrepreneurs: Providing Conceptual Clarity and Future Directions. International Journal of Management Reviews, 23(1), 64-84.

Werthes, D., Mauer, R., \& Brettel, M. (2018). Cultural and creative entrepreneurs: understanding the role of entrepreneurial identity. International Journal of Entrepreneurial Behavior and Research, 24(1), 290-314.

Zhao, H., Seibert, S. E., \& Hills, G. E. (2005). The mediating role of self-efficacy in the development of entrepreneurial intentions. Journal of Applied Psychology, 90(6), 1265.

Żur, A. (2020). Entrepreneurial identity and social-business tensions-the experience of social entrepreneurs. Journal of Social Entrepreneurship, 1-24.

Zygmunt, J. (2018). Entrepreneurial activity drivers in the transition economies. Evidence from the Visegrad countries. Equilibrium. Quarterly Journal of Economics and Economic Policy, 13(1), 89-103.

\section{Authors}

The first two authors share is $50 \%$ (ca. $25 \%$ each of them) and remaining authors' contribution is equal (ca. $16.7 \%$ each of them)

\section{Majid Murad}

Postdoctoral Researcher and PhD holder in management science and engineering from the School of Management at Jiangsu University, China. He published many research articles in renowned journals. His research interest mainly focuses on entrepreneurship (entrepreneurial intention, behaviours, personality, SMEs innovation and self-organized entrepreneurship behaviour).

Correspondence to: Dr. Majid Murad, Jiangsu University (China), 301 Xuefu Rd, Jingkou, Zhenjiang, Jiangsu, China, e-mail: majidmurad1@gmail.com

ORCID (1) http://orcid.org/0000-0003-1465-6724

\section{Sheikh Farhan Ashraf}

Postdoctoral researcher and PhD holder management science and engineering from the School of Management at Jiangsu University, China. He published many research articles in renowned journals. His research interest mainly focuses entrepreneurship (family business, entrepreneurial performance, organizational performance, SMEs, and self-organized entrepreneurship behaviour).

Correspondence to: Dr. Sheikh Farhan Ashraf Jiangsu University (China), 301 Xuefu Rd, Jingkou, Zhenjiang, Jiangsu, China, e-mail: fhsheikh08@yahoo.com

ORCID (1) http://orcid.org/0000-0003-0439-6682

\section{Nausheen Syed}

Assistant Professor in the Department of Business Administration, Government College Women University, Faisalabad, Pakistan. Her research interest mainly focuses on organizational behaviour, entrepreneurship, and family business and SME development.

Correspondence to: Ms. Nausheen Syed, Government College Women University, Arfa Kareem Road Faisalabad, Pakistan, e-mail: nausheen.dr@gmail.com

ORCID (1) http://orcid.org/0000-0002-7246-1012 


\section{Muhammad Munir}

Assistant Professor in the Department of Management and Administrative Sciences, University of Narowal, Norowal, Pakistan. His research interest mainlsy focuses on organizational behaviour, entrepreneurship, and human resource development.

Correspondence to: Dr. Muhammad Munir, University of Narowal, Pakistan, e-mail: muhammad.munir@uon.edu.pk

ORCID (1) http://orcid.org/0000-0002-4047-4150

\section{Rehan Sohail Butt}

$\mathrm{PhD}$ in management science and engineering from the School of Management at Jiangsu University, China. He published many research articles in renowned journals. His research interest mainly focuses employee job satisfaction, entrepreneurship, organizational performance, and SMEs innovation.

Correspondence to: Dr. Rehan Sohail Butt, Jiangsu University (China), 301 Xuefu Rd, Jingkou, Zhenjiang, Jiangsu, China, e-mail: 5103170238@stmail.ujs.edu.cn

ORCID (i) http://orcid.org/0000-0003-2582-8456

\section{Acknowledgements and Financial Disclosure}

We would like to thank anonymous reviewers and editors for their constructive feedback for improving this study. Their comments and suggestion helped us to enhance the robustness of our research. We are also thankful to Pakistani university students for providing us the survey data to complete this research article on the topic of entrepreneurship.

\section{Conflict of Interest}

The authors declare that the research was conducted in the absence of any commercial or financial relationships that could be construed as a potential conflict of interest.

\section{Copyright and License}

This article is published under the terms of the Creative Commons

Attribution - NoDerivs (CC BY-ND 4.0) License

http://creativecommons.org/licenses/by-nd/4.0/

Published by Cracow University of Economics - Krakow, Poland 
